\title{
A Representação da Linguagem em Capas de Gramática: uma Abordagem Semiótica
}

Representation of Language in Covers of Grammar Books: a Semiotics Approach

\author{
Ana Paula Pinheiro da SILVEIRA* \\ Antonio Lemes GUERRA JUNIOR** \\ Loredana LIMOLI***
}

Resumo: Este artigo propõe discutir o modo como a linguagem aparece representada, por meio de um processo de semiotização, em capas de gramáticas brasileiras. Baseando-se nos preceitos teóricos relativos ao fenômeno da gramatização de uma língua e, também, às concepções de linguagem, as capas de alguns exemplares gramaticais serão analisadas, partindo-se das significações que emanam das pistas deixadas em sua superfície textual, sob uma perspectiva semiótica. Além disso, espera-se lançar reflexões acerca dos novos rumos tomados pelas concepções gramaticais e linguísticas no país.

Palavras-chave: Gramática. Linguagem. Semiótica.

Abstract: This paper aims to discuss how language appears represented, in a semiotic process, in covers of Brazilian grammars. Based on theoretical principles concerning the phenomenon of grammatization of a language and also the conceptions of language, the covers of some grammars will be

\footnotetext{
* Mestre em Linguística, pela Universidade Federal de Santa Catarina (2004). Doutoranda em Estudos da Linguagem, pela Universidade Estadual de Londrina (UEL). Docente na Universidade Norte do Paraná (UNOPAR). Contato: paulasilveira.luce@gmail.com. ** Mestre em Estudos da Linguagem, pela Universidade Estadual de Londrina (2011). Doutorando em Estudos da Linguagem, pela Universidade Estadual de Londrina. Contato: junior.guerra@hotmail.com.

*** Doutora em Letras, pela Universidade Estadual Paulista Júlio de Mesquita Filho (1997). Docente na Universidade Estadual de Londrina. Contato: anaderol@sercomtel.com.br.
} 
analyzed, starting from the meanings that emanate from the clues left in their textual surface, from a semiotic perspective. Moreover, it is expected to launch reflections on the new direction taken by the grammatical and linguistic concepts in the country.

Key-words: Grammar. Language. Semiotics.

\section{Introdução}

Atualmente, no Brasil, alguns estudos vêm sendo desenvolvidos no campo da chamada História das Ideias Linguísticas (HIL), cujo intuito é "estabelecer e difundir estudos sistemáticos que tocam a questão da história do conhecimento lingüístico e da história da língua, articuladamente", visando a "conhecer a língua e o saber que se constrói sobre ela ao mesmo tempo em que se pensa a formação da sociedade e dos sujeitos que nela existem" (ORLANDI, 2001, p. 9).

A base desses estudos é metalinguística; por meio dela, a linguagem explica a própria linguagem, com análises de variados materiais, capazes de explicar/sintetizar a história da (r)evolução linguística ocorrida no país. Exemplos desse conjunto de importantes pesquisas podem ser encontrados nos trabalhos de Auroux (1992, 1994, 1998), Guimarães e Orlandi (1996), Orlandi e Guimarães (2001), entre outros.

No caso deste artigo, o foco é operar uma análise pautada na observação de um objeto específico: a gramática (livro/instrumento). Estudos dessa natureza já foram desenvolvidos, como o de Dias (2010), em que a autora contrapõe as informações contidas nas capas de duas edições $\left(8^{\mathrm{a}} \mathrm{e}\right.$ $\left.37^{a}\right)$ da "Moderna Gramática Portuguesa", de Evanildo Bechara, salientando os aspectos editoriais que denotam sua evolução, especialmente o título.

Partindo do mesmo objeto, pretendemos discutir como as concepções de linguagem aparecem refletidas na composição sincrética das capas dessa e de outra gramática brasileira. Assim, nos próximos itens, será percorrido um trajeto que parte das noções de gramatização, perpassa as concepções e deságua nas análises, que evidenciam a fluidez do histórico rio da linguagem. 


\section{Linguag,em, Escrita e Gramática: a (r)evolução do conhecimento linguístico}

O território da linguagem abarca estudos variados, inclusive aqueles que permitem compreender melhor a constituição das identidades de um sujeito, de uma nação. Entretanto, as ciências da linguagem só foram possíveis a partir da escrita, a qual, segundo Auroux (1998, p. 71), "conduz a transformações profundas das práticas linguageiras”. Ela, a escrita, seria

[...] uma resposta específica a uma série de problemas técnicos, nascidos bem antes dela e parcialmente solucionados pelas técnicas gráficas que a anunciam. [...] Ela muda qualitativamente a natureza das ligações sociais e, porque torna possivel a escrita da lei e da ciência, ela faz nascerem novas formas de liberdade humana. (AUROUX, 1998, p. 69 - grifos nossos).

Se, como salienta o autor, a escrita propicia o registro da lei e da ciência, é válido tomá-la como a responsável por grande parte do processo evolutivo da humanidade. É o surgimento e o desenvolvimento dos suportes gráficos que vão colaborar na movimentação, no aprimoramento do saber linguístico humano.

Diante dessa importância atribuída à escrita, é necessário pensar no fato de que, com ela, foram possíveis os registros que inscrevem a linguagem no tempo, explicam suas especificidades, dando origem a documentos valiosos para o resgate histórico dessa mesma linguagem. Assim, nos itens a seguir, serão discutidos o processo de gramatização, a elaboração de gramáticas e o modo como elas corroboram a definição de uma identidade linguística nacional.

\subsection{O processo de gramatização de uma língua: as metalinguagens}

Quando se fala em linguagem, fala-se, também, em "saber". O homem é dotado de um saber linguístico, definido por Auroux (1992, p. 16) como um saber epilinguistico, uma espécie de saber inconsciente, do sujeito falante, um saber internalizado. Com o desenvolvimento da escrita, tiveram início as representações da linguagem, sua descrição, sua explicação. Assim, configurou-se o que se denomina um saber metalinguístico, elaborado, específico, construído e manipulado por meio de normas e tecnologias. 
Enquanto o saber epilinguístico é múltiplo e principia naturalmente na consciência do homem, como postula Auroux (1992), o saber metalinguístico surge com a ajuda de uma metalinguagem, a partir da qual os signos passam a receber nomes. É dentro desse panorama de sistematização do saber linguístico que se percebe o processo da gramatização, pelo qual "deve-se entender o processo que conduz a descrever e instrumentar uma língua na base de duas tecnologias, que são os pilares de nosso saber metalingüístico: a gramática e o dicionário” (AUROUX, 1992, p. 65).

A ideia de "gramática" está intimamente vinculada à escrita e, portanto, à sistematização, à representação. Etimologicamente, a palav ra gramática tem origem no grego gramma (letra); isso justifica a postulação de Auroux (1992), quando o autor diz que tudo parece mostrar que não existe verdadeiro saber gramatical oral, ou seja, é a escrita que permite um "pensar" sobre a linguagem: "o processo de aparecimento da escrita é um processo de objetivação da linguagem, isto é, de representação metalinguística considerável e sem equivalente anterior" (AUROUX, 1992, p. 20).

Nos primórdios das interações linguísticas humanas, não havia a necessidade de uma gramática, "um corpo de regras explicando como construir palavras, mesmo que sob a forma implícita de paradigmas" (AUROUX, 1992, p. 25), para aprender a falar. A tradição gramatical surge não da necessidade de se falar uma língua, mas da necessidade de compreender um texto, daí sua base sistematizadora, reguladora, que permite olhares organizados sobre a linguagem.

A criação de materiais como as gramáticas revolucionaram o trabalho com a linguagem, pois, por meio delas, há a possibilidade de definir, compreender, organizar, reformular uma língua, a partir do registro de suas características básicas, extraídas de sua manifestação no uso pelo falante. Afinal, segundo Orlandi (2001, p. 8), ver as gramáticas

[...] como parte da relação com a sociedade e com a história, transforma esses instrumentos em objetos vivos, partes de um processo em que os sujeitos se constituem em suas relações e tomam parte na construção histórica das formações sociais com suas instituições, e sua ordem cotidiana. 


\subsection{A gramatização no Português Brasileiro ${ }^{1}$}

Orlandi e Guimarães (2001, p. 21-38), em seu texto "Formação de um espaço de produção lingüística: a gramática no Brasil”, trazem considerações referentes à articulação entre a história das ideias linguísticas e a história da constituição da língua nacional. Segundo eles (2001, p. 21), esse processo "traz novos elementos para a compreensão da gramática e a explicação da relação da língua com o Estado”. Para os autores, a constituição da língua nacional está, de algum modo, condicionada ao domínio do Estado. Assim, para discutir o processo de gramatização ocorrido no português brasileiro, deve-se verificar, também, como essa "articulação" se deu no Brasil, enquanto um país colonizado por europeus.

Inicialmente, é importante resgatar o momento do descobrimento do país pelos portugueses. Àquela época, ocorre um fato decisivo: a língua portuguesa foi "transportada" para cá, começando a ser "falada" em um novo "espaço-tempo". Isso demonstra que a língua assumiu novas características desde que passou a ser utilizada pelos habitantes da nova terra, o que deu a ela condições de se desenvolver de modo diferente. Segundo Orlandi e Guimarães (2001), todo esse processo, que ainda continua até os nossos dias, passou por vários momentos.

O primeiro vai do início da colonização até a expulsão dos holandeses em 1654. A língua portuguesa é falada por poucos, devido à grande predominância de índios e negros na população. A língua indígena é tomada como "língua geral", sendo utilizada para as questões comerciais, embora o português já comece a ser colocado como língua do Estado, ensinado em escolas católicas e documentos oficiais.

O segundo vai de 1654 a 1808, data da chegada da família real portuguesa ao Brasil, concomitante à invasão de Portugal por Napoleão. A crescente chegada de portugueses ao país leva a um maior domínio por parte da língua portuguesa, deixando em segundo plano a "língua geral". O ensino do português passa a ser imposto nas escolas, ao mesmo tempo em que se proíbe o ensino de línguas indígenas.

1 A intenção desse item é apenas discutir, de forma breve, os caminhos que levaram à gramatização da língua portuguesa no Brasil. Portanto, optamos por não abordar as características das diversas gramáticas elaboradas no país. 
Para o terceiro momento, tem-se, como marco inicial, a chegada da família real portuguesa no Brasil, estendendo-se até 1826, período em que a língua portuguesa como língua nacional no Brasil é oficialmente formulada. A criação da imprensa e da Biblioteca Nacional dá suporte à confirmação de unidade do português no país, visto como a língua do rei e, portanto, do povo.

Por fim, o quarto momento começa em 1826, quatro anos depois da independência do Brasil. Nesse período, são salientes as diferenças entre o português falado em Portugal e o português falado no Brasil, que já se desenvolve com peculiaridades que o identificam como uma hiperlíngua ${ }^{2}$ (AUROUX, 1994). Além disso, tem início o processo brasileiro de gramatização, com instrumentos linguísticos específicos, que passam a guiar a língua aqui utilizada.

Todo esse processo evolutivo culminou no aumento da produção de trabalhos baseados no estudo da língua no Brasil, no final do século XIX. É neste período que começam a surgir as primeiras gramáticas brasileiras, dando forma ao processo de "gramatização", pelo qual o português brasileiro passa a se distanciar de sua origem portuguesa.

Nessa época, como já salientado, começam a surgir gramáticas que tentam regularizar o uso da língua utilizada no país. Como exemplo, Orlandi e Guimarães (2001) apontam o "Programa de Português para os Exames Preparatórios", de Fausto Barreto, considerado um marco no processo de gramatização, que leva à produção de vários outros trabalhos que "dizem querer romper com a tradição portuguesa da gramática filosófica" (ORLANDI; GUIMARÃES; 2001, p. 25). Trata-se de um verdadeiro "renascimento dos estudos da língua vernácula" (ORLANDI; GUIMARÃES; 2001, p. 26).

A partir daí, o que se tem é a construção de um longo caminho de produção gramatical no Brasil, com o surgimento de grandes nomes. Por isso, vale lembrar a importância que têm os gramáticos na história da constituição da língua nacional, uma vez que estes são vistos como vozes de autoridade, ocupando uma posição de respeito e confiabilidade no âmbito dos estudos linguísticos.

${ }^{2}$ Hiperlíngua: basicamente, a realização de uma manifestação linguística em um espaço-tempo estruturado pelos objetos e pelos sujeitos que o ocupam. 


\subsection{A constituição da identidade linguística nacional a partir das gramáticas}

É possível afirmar que há uma estreita relação entre o processo de gramatização de uma língua e a construção da identidade linguística de uma nação, tendo como base, neste caso, a história do português no Brasil e a sua trajetória enquanto uma língua nacional em vias de consolidação.

Segundo Orlandi e Guimarães (2001, p. 32), “a construção de tecnologias", como gramáticas, que caracteriza o processo de gramatização, "faz parte da história de uma sociedade". Para os autores, "pela análise da produção destes instrumentos tecnológicos, podemos compreender igualmente a maneira pela qual a sociedade brasileira constituiu-se".

Em outras palavras, regularizar o uso de uma língua, seja por meio da criação de gramáticas ou de dicionários, é um meio de dar forma à identidade de uma nação dotada de habilidades linguísticas peculiares, que refletem sua história. Nesse contexto, pode-se retomar o conceito de "hiperlíngua", que caracteriza o português brasileiro, construído em outro espaço e em outro tempo, o que o legitima como a língua nacional brasileira, historicamente constituída.

Os estudos linguísticos mostram-se muito importantes para a compreensão de uma língua enquanto constituinte da identidade de uma nação. Dentro desse processo, as gramáticas têm papel central, pois se destacam como materiais fundamentais que guiam os sujeitos no conhecimento de sua língua, colaborando na construção da "forma histórica do sujeito brasileiro" (ORLANDI; GUIMARÃES, 2001).

Caracterizado pela sua variedade em termos de manifestação, o português brasileiro distancia-se de seu referente europeu. Como apontam Orlandi e Guimarães (2001, p. 34), “a unidade necessária do português brasileiro referido a seu funcionamento histórico determinado é uma marca de sua singularidade". Assim, ressaltam os autores, "a variação não tem como referência Portugal, mas a diversidade concreta produzida neste outro território, este novo espaço de linguagem" (a hiperlíngua brasileira).

Esse distanciamento de suas raízes originais, que caracteriza o processo de gramatização do português brasileiro, pode ser percebido, também, nas análises que este artigo propõe. A seguir, portanto, passaremos a discutir questões relativas às diferentes concepções de linguagem, as quais permitirão verificar como as gramáticas brasileiras se valem desses sentidos. 


\section{Desvendando as Concepções de Linguagem}

A gramática, neste artigo, como sublinhado, é analisada na visão de Auroux (1992), como instrumento linguístico resultante do processo de gramatização. É importante notar que, nessa perspectiva, a língua deriva do domínio do Estado, portanto, a produção do saber metalinguístico é regulada por dois movimentos imbricados: o papel legislador do Estado; o papel regulador da instrução e tradição gramatical (ORLANDI; GUIMARÃES, 2001). Isso se traduz também no que é expresso nas capas das gramáticas.

Compreender o movimento do "português brasileiro" inclui considerar, de forma efetiva, as concepções de língua, de ensino e o que preconizavam os documentos do ensino da língua no território nacional.

Bagno (2004), na introdução do seu livro, afirma que o grande desafio do professor no limiar do século XXI é saber se deve ensinar "português" ou "brasileiro". Assevera a necessidade de o professor decidir seguir o já definido como um conjunto de regras, baseado na língua escrita e literária e, consequentemente, no português falado em Portugal; ou dar voz à língua falada no Brasil por um número muito maior de falantes, 17 vezes a população de Portugal, e considerar que a língua é heterogênea e precisa ser analisada a partir de um aparato teórico metodológico e científico que permita distinguir as especificidades do português falado no Brasil.

Matos e Silva (2004) corrobora a posição de Bagno (2004), ao reiterar que o Brasil é um país de grande extensão territorial, heterogeneidade cultural, social e econômica - nação da diversidade, portanto, sua língua é reflexo dessa diversidade, embora uma visão redutora insista na "espantosa", "notável", "esplêndida", "apreciável" unidade do português do Brasil e, por isso, defenda o uso da língua lusitana, chegando a utilizar clichês generalizantes de puristas que definem a nossa língua como "empobrecimento", “decadência".

Essa tentativa de ensinar um português expresso pela gramática de tradição lusitana vai certamente trazer consequência para o fracasso do ensino da língua no Brasil.

Castilho (2002) acredita que a distância entre a linguagem utilizada socialmente pelo aluno e o que é ensinado nas aulas de língua portuguesa é um dos fatores responsáveis pela má qualidade do ensino. Segundo ele, esses resultados estão relacionados a dois comportamentos contrários: o primeiro é o de privilegiar a língua escrita como fonte do padrão; a segunda, 
de pautar o ensino em procedimentos didáticos que defendem uma visão simplista da linguagem, na qual considera que tudo é válido. Para ele, “o mais adequado será sensibilizar o aluno para a variabilidade lingüística, correlacionando-se com as situações a que corresponde" (CASTILHO, 2002, p. 29).

Há uma concordância entre os autores no sentido de concluírem que existem problemas no ensino da língua portuguesa, e as causas podem ser vistas no distanciamento entre o português brasileiro, utilizado nas interações sociais, e o normatizado pela gramática no estudo da metalinguagem. Partindo dessas conclusões, compreende-se a necessidade de trazer para a discussão deste artigo os conceitos das concepções de linguagem, que, como afirma Geraldi (2004), estão atreladas à compreensão de dois aspectos fulcrais: saber por que se ensina a língua e o que deve ser ensinado na escola.

Não podemos tecer considerações sobre os conceitos de gramática, dissociando-os do percurso da linguística como ciência, que influenciou o modo de concebê-los. Nesse sentido, é importante considerarmos que a história da linguística, em grandes linhas, passa por três momentos que podem ser resumidos como: “estrutura” (1960-1970); “enunciação" (1970-1980); "interação” (1980-1990). Essas vertentes vão influenciar o modo como os teóricos que produzem os instrumentos de gramatização exprimem suas características e concepções e possibilitam ao pesquisador olhar a língua sob enfoques teóricos divergentes, para entender se a gramática está sendo compreendida sob a perspectiva do enunciado, resultado das interações linguísticas; ou como enunciação, no qual estão envolvidos os parceiros da comunicação (interlocutores), bem como as condições de produção do discurso. Isto posto, podem-se compreender as relações imbricadas entre as teorias linguísticas e as concepções de linguagem.

\subsection{Linguagem como expressão do pensamento}

Sustentada pela tradição gramatical grega, a concepção de linguagem como expressão do pensamento encontra suas origens nas primeiras sistematizações das gramáticas com os latinos e contempla a sua ruptura desencadeada pelos estudos de Saussure.

No "Curso de Linguística Geral", Saussure (1972) define a linguagem como uma abstração, a capacidade que o homem possui de comunicar-se com seus semelhantes por meio dos signos. A língua é um conjunto de 
regras (semânticas, morfológicas, fonológicas e sintáticas) necessárias para a comunicação, e sua expressão é produzia no interior da mente do indivíduo. A linguagem é, nesta perspectiva, tradução do pensamento, como assevera Travaglia (1997, p. 21):

A expressão se constrói no interior da mente, sendo sua exteriorização apenas uma tradução. A enunciação é um ato monológico, individual, que não é afetado pelo outro nem pelas circunstâncias que constituem a situação social em que a enunciação acontece.

Essa concepção, baseada no estudo da língua como enunciado, fundamenta o ensino tradicional, uma vez que corresponde à corrente de estudos da gramática normativa. O termo "expressão" está para significar a única função do estudo da língua: levar o aluno a expressar-se corretamente, conforme a norma padrão.

\subsection{Linguagem como instrumento de comunicação}

A publicação do trabalho de Saussure, no final do século XX, instaura uma ruptura com os estudos linguísticos comparativos que o precederam. Se, de um lado, observamos que a concepção de língua vista como tradução do pensamento sustenta a primeira concepção de linguagem, de outro, a sua proposta de um método sincrônico de análise linguística, bem como a importante dicotomia entre langue e parole vão propiciar que novos estudos sejam empreendidos.

$\mathrm{Na}$ esteia de Saussure, estudiosos da linguagem vão desenvolver trabalhos influenciados pela teoria da comunicação, sustentando uma concepção de linguagem que concebe a língua como um código, a comunicação é reduzida a uma forma vazia, em que o emissor é ativo e o receptor, passivo. O centro é a informatividade da mensagem, o modo de funcionamento da comunicação e não o ato de linguagem.

Karl Bühler foi um dos seus precursores. Baseado nos três fatores básicos para a linguagem - o destinador, o destinatário e o contexto -, formulou três funções para a linguagem verbal: expressiva ou sintomática (centrada no destinador); sinal (centrada no destinatário); descrição ou representação (centrada no contexto). 
Posteriormente, o linguista Roman Jakobson ampliou para seis as funções da linguagem. Conforme a ênfase dada a um dos elementos da comunicação - emissor, receptor, canal, código, referente, mensagem -, teríamos respectivamente uma função da linguagem: emotiva, apelativa, fática, metalinguística, referencial, poética.

As grandes linhas teóricas da linguística que sustentaram essa concepção foram o estruturalismo e o gerativismo.

Dois fatos relevantes estão intimamente relacionados à proposta de ensino, sustentada pela concepção de linguagem como comunicação: a promulgação as Leis de Diretrizes e Bases 5692/71, em que a Língua Portuguesa passa a integrar a área de Comunicação e Expressão ${ }^{3}$, e a concepção tecnicista de ensino, na qual a aprendizagem é compreendida como internalização de hábitos, conforme a teoria behaviorista.

\subsection{Linguagem como processo de interação}

Como argumenta Bakhtin (1995, p. 113), “[...] toda palavra comporta duas faces. Ela é determinada tanto pelo fato de que procede de alguém, como pelo fato de que se dirige para alguém". Assim, a compreensão de que o indivíduo, ao utilizar a língua, não realiza somente o exercício de traduzir e exteriorizar um pensamento elaborado em sua mente ou de transmitir informações ao seu interlocutor (receptor), mas que realiza ações, age sobre o outro, levou ao estudo e à sistematização da concepção da linguagem como interação.

Os estudos da linguística da enunciação sustentam esta concepção da linguagem e inspiram novas pesquisas no âmbito do ensino da língua. Exemplo disto foi a publicação dos Parâmetros Curriculares Nacionais (BRASIL, 1998), que inaugurou uma mudança importante em relação ao objeto de ensino: a gramática normativa deixa de ser o eixo progressivo dando lugar ao texto, aos gêneros presentes na esfera social.

Apesar de as outras concepções ainda estarem presentes no ensino, esta última, influenciada pela teoria da enunciação e dos atos de fala, a análise do discurso e o sociointeracionismo discursivo, está sempre ganhando mais espaço.

${ }^{3}$ Incluídas ainda, nesta área, Educação Física, Educação Artística e Língua Estrangeira. 


\section{A Linguagem Semiotizada nas Capas da Moderna Gramática da Língua Portuguesa, de Evanildo Bechara}

Em 1961, foi publicada a Moderna Gramática Portuguesa, do professor, gramático e filólogo brasileiro, Evanildo Bechara. Atualmente em sua $37^{\mathrm{a}}$ edição, revista, ampliada e atualizada, a obra destaca-se por sua completude e seriedade. Em sua longa trajetória, é natural que tenha sofrido mudanças substanciais, as quais começam a ser percebidas na composição das capas que recobrem seus diversos exemplares.

Por esse motivo, nossa intenção, a partir de agora, é propor uma análise dos sentidos passíveis de serem extraídos das imagens das capas de algumas de suas edições $\left(8^{\mathrm{a}}-1963 ; 28^{\mathrm{a}}-1983 ; 37^{\mathrm{a}}\right.$ - 2009), relacionando-os às concepções de linguagem. ${ }^{4}$

A análise aqui empreendida tomará como base os preceitos postulados pela Teoria Semiótica Greimasiana . O objeto de estudo dessa teoria é a significação, ou seja, os efeitos de sentido criados pelos textos. Sua finalidade é "descrever e explicar o que o texto diz e como ele faz para dizer o que diz" (BARROS, 2007), concebendo a linguagem como "sistema de significações" ou como "sistema de relações", pois, como explica Barros (2002), "a significação decorre da relação". Nesse sentido, a Semiótica parte do pressuposto de que, se há significações, elas podem ser explicadas por meio da linguagem. Este é o grande desafio da Teoria Semiótica e, agora, de nossas proposições, elencadas a seguir.

\subsection{Capa da $8^{\mathrm{a}}$ edição (1963)}

Ao discutirmos a concepção de linguagem como expressão do pensamento, dissemos que, a partir dessa perspectiva, o primordial no estudo

\footnotetext{
${ }^{4}$ Os critérios para a seleção dos objetos de análise centraram-se: i) na importância da obra e do autor no cenário gramatical brasileiro; ii) na viabilidade de acesso às edições; iii) e, especialmente, na configuração visual das capas, que permitiram tornar visível, por meio da leitura semiótica, dois movimentos imbricados - o papel do legislador do Estado e o papel regulador da instrução e tradição gramatical - vistos a partir da publicação dos Parâmetros Curriculares Nacionais e das concepções de linguagem e ensino ligadas a cada uma dessas gramáticas, bem como da busca de uma identidade nacional, expressa nas gramáticas do português brasileiro, discutidas no item 4 .

${ }^{5}$ Doravante, apenas Semiótica.
} 
da língua é o "expressar-se corretamente, segundo os ditames da norma padrão”. E, quando se fala em padrão, fala-se em regras, as quais muitas vezes "engessam" o ensino e as próprias produções linguísticas. Sendo esse, por muito tempo, o papel da gramática (impor normas), a $8^{a}$ edição de nosso objeto de estudo traz, em sua capa, elementos que nos permitem estabelecer relações com essa concepção.

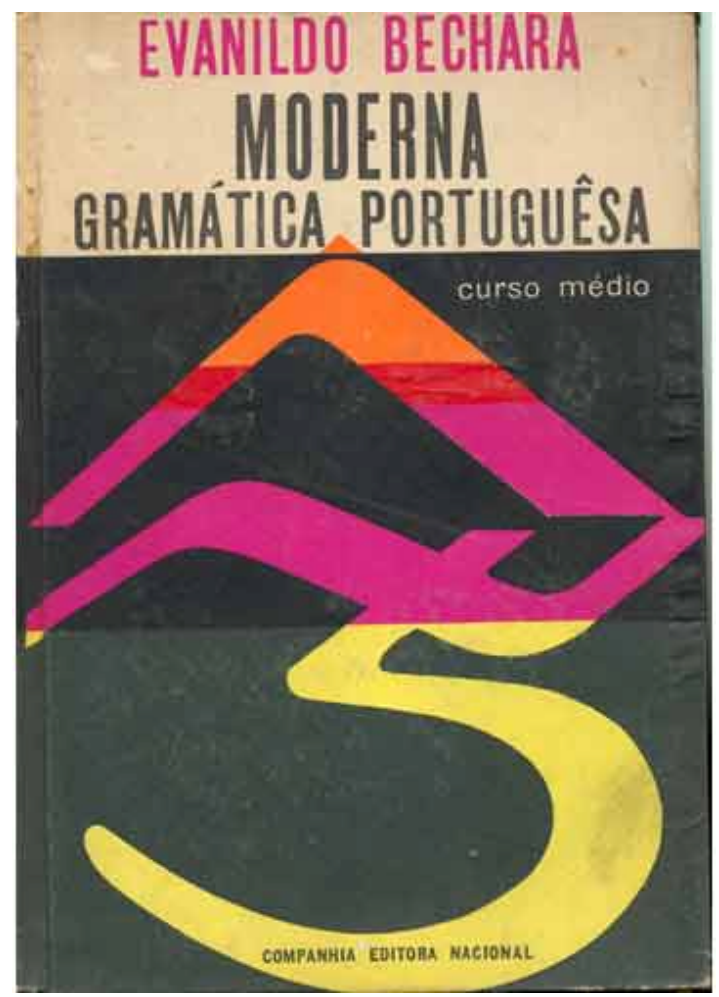

Figura 1 - Capa da $8^{a}$ edição (1963)

Inicialmente, o que chama a atenção é a imagem construída a partir da criação de um símbolo, o qual associa três "sinais", extremamente ligados à ideia de norma, de regra: o acento circunflexo, o til e a cedilha. Ocorre aí um processo de figurativização: o tema da norma, à primeira vista, abstrato, recebe investimentos figurativos, sendo concretizado, materializado, no 
discurso da capa. Em outras palavras, o enunciador cria um cenário responsável por manifestar o tema (FIORIN, 2006). ${ }^{6}$

Pode ser percebida na capa, também, a ortografia vigente à época, visível no título da obra, em que a palavra "portuguesa" aparece acentuada, diferente do que ocorre na atualidade, depois de uma série de reformas ortográficas. Aliás, essa evolução da ortografia caminha junto à evolução do sistema de ensino, indicado pela expressão "curso médio", evidenciando a presença da escola como um espaço de aquisição das regras gramaticais.

Por fim, pode-se fazer menção às cores empregadas. $\mathrm{O}$ símbolo, no centro da capa, aparece colorido com nuances fortes, adquirindo bastante evidência sobre uma superfície predominantemente escura. Ocorre, assim, um confronto entre clareza e obscuridade, pautado nas conotações culturalmente atribuídas às cores. Farina, Perez e Bastos (2006), por exemplo, apontam que, para uma cor como o preto, utilizado na constituição da capa, ocorre uma associação material ligada a "coisas escondidas, obscuras" e uma associação afetiva que remete à "seriedade" (FARINA; PEREZ; BASTOS, 2006, p. 97). Cores como o laranja e o amarelo são associadas, materialmente, à "luz" e, afetivamente, à "iluminação", à "luminosidade" (FARINA; PEREZ; BASTOS, 2006, p. 100-101). Desse modo, uma vez construído a partir de sinais gráficos ligados à esfera gramatical, o símbolo, iluminado pelas cores, relaciona-se à tarefa da obra que se pretende clara: desvendar/clarificar possíveis dificuldades gramaticais.

${ }^{6}$ Fiorin (2008) ressalta que a figurativização é um nível de concretização do sentido. Assim, em um texto sincrético, como é o caso das capas aqui analisadas, em que se fundem as linguagens verbal e não verbal, esse processo é de fundamental importância, pois, quanto mais concreto, mais visível for o sentido, mais significações podem ser extraídas. A figura ainda pode ser definida como o "termo que remete a algo existente no mundo natural" (FIORIN, 2008, p. 91), podendo ser exemplificada por objetos, pessoas, animais, plantas, cores, enfim, qualquer coisa que pode ser identificada na realidade, no caso, na realidade do mundo da linguagem. Por isso, com esses investimentos de figuras, criamos discursos figurativos, que "criam um efeito de realidade, pois constroem um simulacro da realidade, representando, dessa forma, o mundo" e que "têm uma função descritiva ou representativa" (FIORIN, 2008, p. 91 - grifos nossos). 


\subsection{Capa da $28^{\text {a }}$ edição (1983)}

Deslocando-se para a ideia de "informatividade da mensagem", o "modo de funcionamento da comunicação", a concepção de linguagem como instrumento comunicativo surge na capa da $28^{a}$ edição da obra analisada. Aqui, não há mais o uso de símbolos abstratos, que, juntos, remetem à noção de padronização. O foco é, visivelmente, o caráter informacional da linguagem.

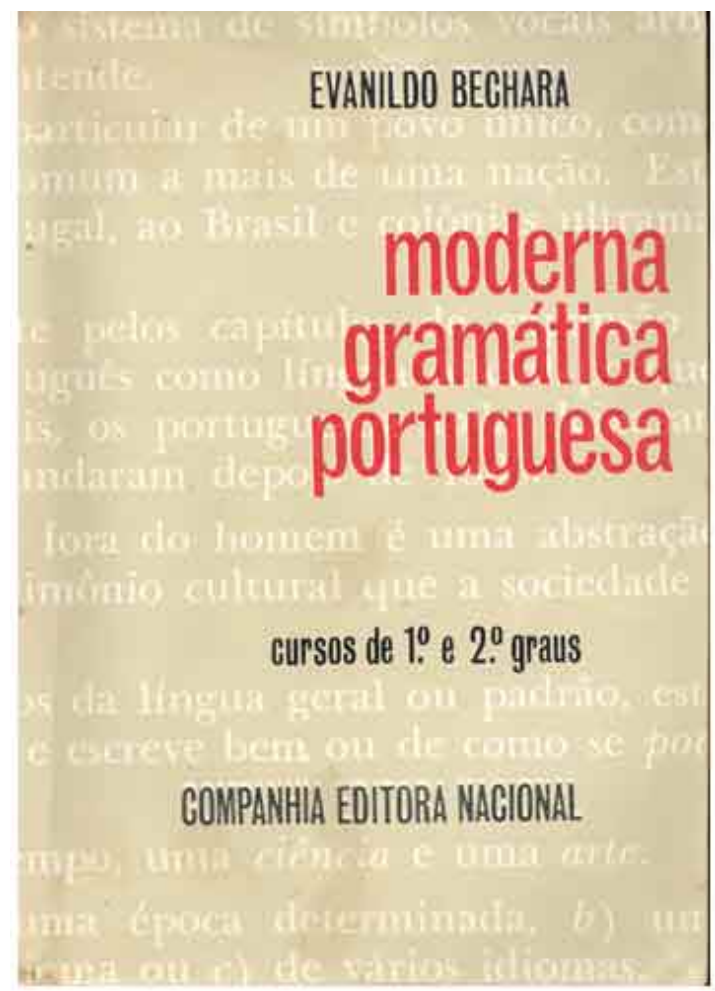

Figura 2 - Capa da 28 edição (1983)

Construída em tonalidades sóbrias, claras, a capa dessa edição traz, em segundo plano, a transcrição de uma "mensagem", muito provavelmente extraída de um dos textos que compõem o interior da obra. Nela, embora 
não seja possível contemplá-la em sua totalidade, podemos compreender alguns trechos-chave, os quais se ligam às funcionalidades da gramática. No quadro a seguir, aparecem destacados alguns deles, com suas respectivas (possíveis) significações:

\begin{tabular}{|c|c|}
\hline Trecho & Relação significativa \\
\hline $\begin{array}{l}\text { "sistema de símbolos } \\
\text { vocais" }\end{array}$ & $\begin{array}{l}\text { Representações gráficas/fonéticas da } \\
\text { linguagem. }\end{array}$ \\
\hline $\begin{array}{l}\text { "particular de um povo } \\
\text { único" }\end{array}$ & $\begin{array}{l}\text { A noção de singularidade linguística (uma } \\
\text { língua assume características que a fazem } \\
\text { pertencer apenas àquele povo). }\end{array}$ \\
\hline $\begin{array}{l}\text { "comum a mais de uma } \\
\text { nação" }\end{array}$ & $\begin{array}{l}\text { A utilização de um mesmo idioma em vários } \\
\text { países. }\end{array}$ \\
\hline "ao Brasil e colônia" & $\begin{array}{l}\text { A imposição da cultura (linguística), no } \\
\text { Brasil, pelos portugueses. }\end{array}$ \\
\hline $\begin{array}{l}\text { "português como } \\
\text { língua" }\end{array}$ & $\begin{array}{l}\text { A noção de português como idioma } \\
\text { oficialmente aceito. }\end{array}$ \\
\hline $\begin{array}{l}\text { "fora do homem é uma } \\
\text { abstração" }\end{array}$ & $\begin{array}{l}\text { As discussões em torno da linguagem } \\
\text { enquanto elemento abstrato. }\end{array}$ \\
\hline $\begin{array}{l}\text { "patrimônio cultural que } \\
\text { a sociedade" }\end{array}$ & $\begin{array}{l}\text { Menção à relevância/importância social da } \\
\text { linguagem. }\end{array}$ \\
\hline "língua geral ou padrão" & $\begin{array}{l}\text { Referência à existência de variantes } \\
\text { normatizadoras. }\end{array}$ \\
\hline "escreve bem" & $\begin{array}{l}\text { Explicitação do papel regulador da } \\
\text { gramática. }\end{array}$ \\
\hline $\begin{array}{l}\text { "uma ciência e uma } \\
\text { arte" }\end{array}$ & $\begin{array}{l}\text { Elevação da linguagem ao estatuto de } \\
\text { ciência. }\end{array}$ \\
\hline $\begin{array}{l}\text { "uma época } \\
\text { determinada" }\end{array}$ & $\begin{array}{l}\text { Relativização da linguagem, que varia no } \\
\text { tempo. }\end{array}$ \\
\hline "vários idiomas" & $\begin{array}{l}\text { Presença de regras, de gramática, em várias } \\
\text { línguas. }\end{array}$ \\
\hline
\end{tabular}

Com esse quadro, podemos estabelecer uma clara relação entre o conteúdo significativo da capa com a concepção de linguagem em questão, pois, a partir de um canal (a capa do livro), diversas mensagens (informações) são transmitidas (comunicadas). No entanto, tudo é feito de forma arbitrária, 
excluindo-se o dialogismo, característico de outra concepção. Por fim, as cores empregadas também significam: o vermelho se destaca, enquanto cor primária, "quente", sobre um fundo policromático de tendência neutra, e esse realce contribui para figurativizar a supremacia da gramática.

\subsection{Capa da $37^{\mathrm{a}}$ edição - atualizada (2009)}

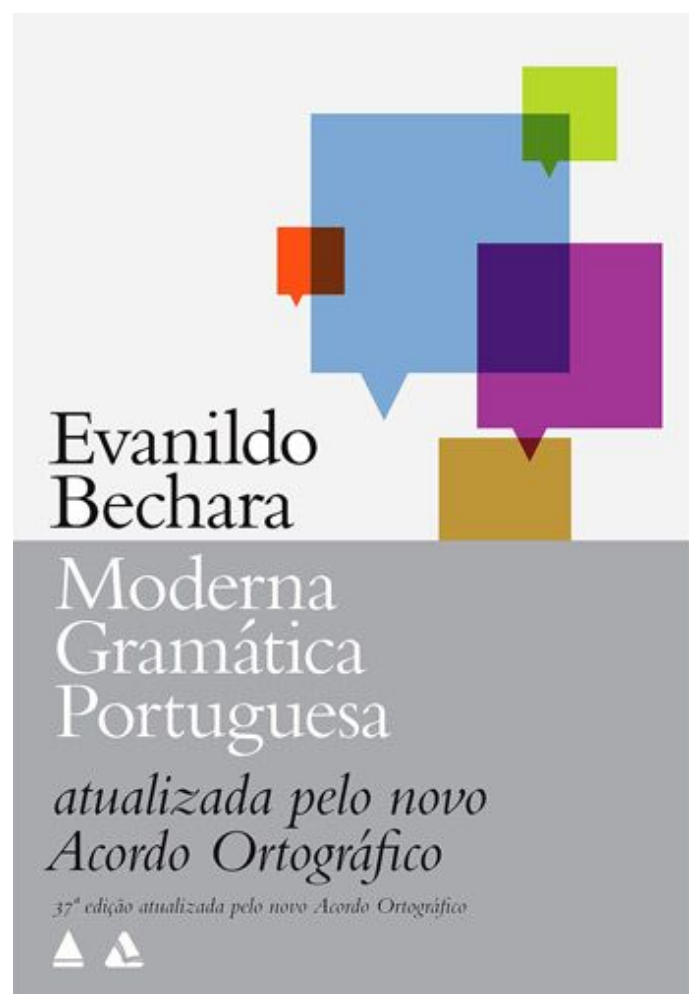

Figura 3 - Capa da 37ª edição - atualizada (2009)

Apresentando, como ponto de partida, a visão de "linguagem como um lugar de interação humana", a terceira concepção vem ao encontro da construção imagética visualizada na capa dessa edição. Os "balões", sugerindo falas, imprimem na obra o caráter dialógico, a relação interacional entre diferentes indivíduos, indo além da simples comunicação, da mera 
transmissão de mensagens. Sobre essas formas gráficas, podem ser feitas observações com base em quatro aspectos: o tamanho; a posição, a sobreposição/intersecção; e a cor.

A dimensão de cada um dos balões e a posição que ocupam na capa evocam os níveis de simetria e assimetria, perceptíveis em um evento conversacional qualquer. Nas interações sociais, o diálogo acontece em turnos; a enunciação parte de um locutor e se dirige a um interlocutor, e sua realização depende das relações de simetria e assimetria que existem entre os parceiros, isto é, se fazem parte do mesmo grupo de amigos, da mesma classe social, se ocupam espaços sociais distintos, se provêm de regiões geográficas diferentes. Neste sentido, as relações entre os balões maiores e os menores podem ser materializadas, por analogia, nas conversas entre uma pessoa mais velha e outra mais jovem, um indivíduo escolarizado e outro de nível cultural inferior, enfim, os balões maiores podem representar uma intensidade mais acentuada de caracteres que distinguem um falante de outro. A fala, na perspectiva interacional, é afetada pelo outro, por isso as marcações assimétricas também surgem da intersecção das formas, que evidencia o quão heterogênea pode ser a interação, com sobreposição de vozes, de discursos.

Quanto às cores, o vermelho, o azul, o verde, o lilás e o marrom, deixando de ser simples tonalidades, reforçam a interpretação de que os conteúdos desses balões provêm de indivíduos, de fato, diferentes. Assim, resgata-se, mais uma vez, a concepção de que são atribuídas conotações culturais ao uso das cores. De acordo com Farina, Perez e Bastos (2006, p. 123), "uma mesma forma com diferentes cores não produz o mesmo sentimento". Os balões - parecidos na forma, diferentes nas cores - sugerem a interação proposta pela gramática, assumida como um locutor, ao qual respondem seus leitores/usuários, posicionados como interlocutores.

Considerar a linguagem a partir de seu caráter interacional constitui, portanto, uma concepção que, materializada na capa de um instrumento de gramatização, como o é a obra de Bechara, inicia um processo de deslocamento da gramática, removendo-a de uma posição prisional, que acorrenta usuários da língua, a uma aparente posição (vale frisar, pelo menos em sua superfície, em sua capa) de reveladora de possibilidades de realização linguística. 


\section{Novos Caminhos da Gramática Brasileira}

No decorrer da análise das gramáticas de Evanildo Bechara, foi possível observar o movimento de mudança de concepção de linguagem e ensino na figurativização expressa em suas capas. As alterações sublinhadas nas análises, porém, não fizeram referência ao português brasileiro. Esse tema emerge nas gramáticas de Castilho (2010) e Castilho e Elias (2012).

Optou-se, neste artigo, por analisar as duas gramáticas de forma conjunta, visto que, na apresentação da Pequena Gramática do Português Brasileiro, os autores declaram que "o livro tem sua origem na Nova Gramática do Português Brasileiro" (CASTILHO; ELIAS, 2012, p. 15), portanto, consideraremos as semelhanças e especificidades das duas obras.

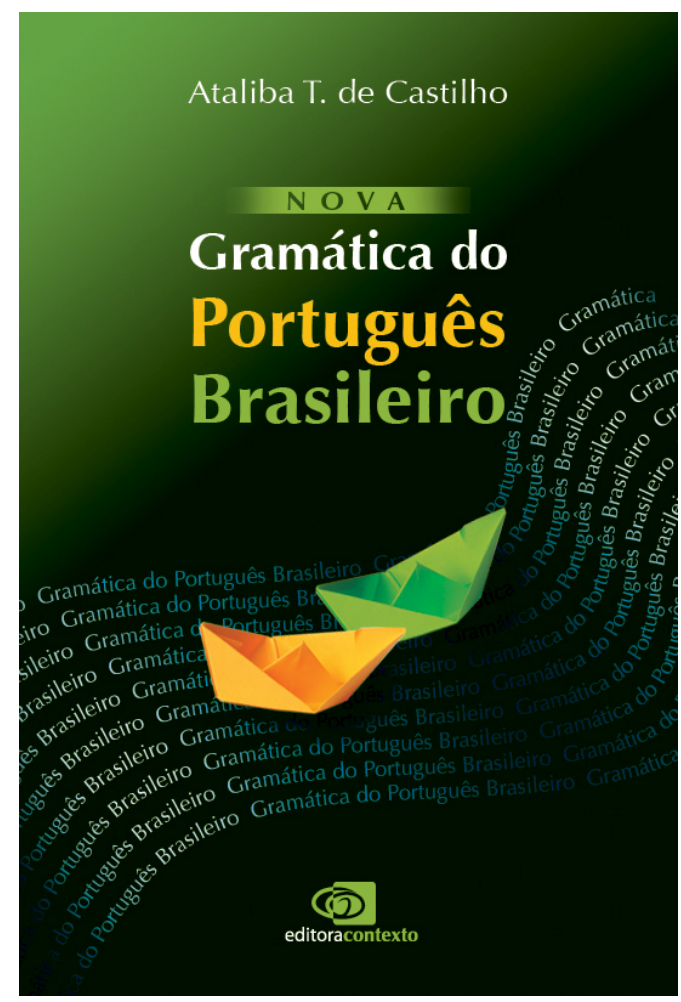

Figura 4 - Capa da Nova Gramática do Português Brasileiro 


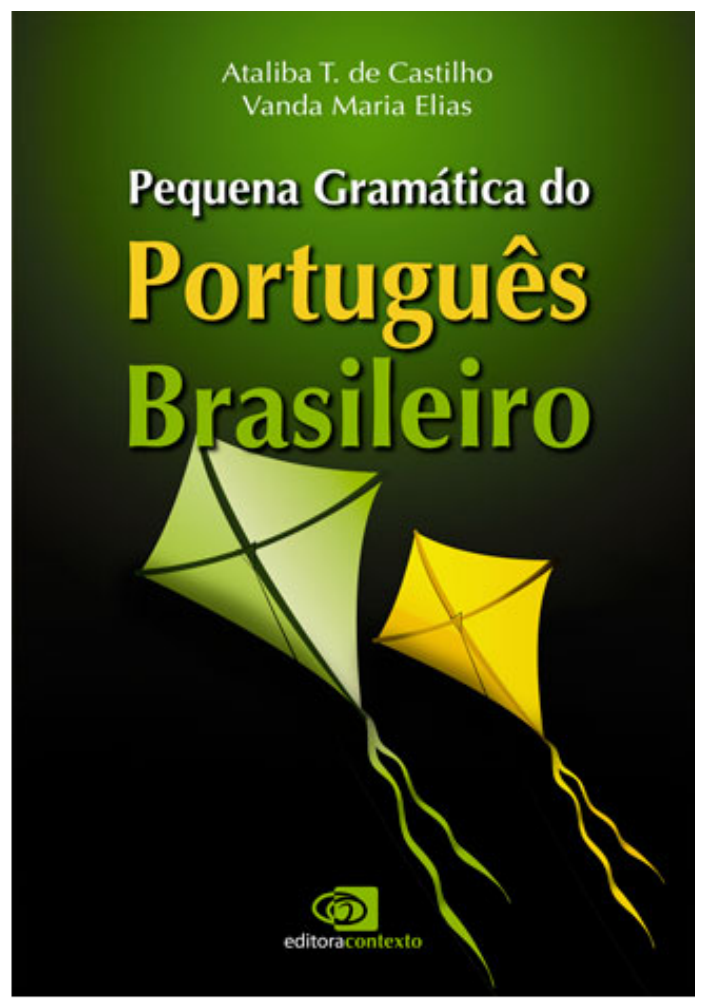

Figura 5 - Capa da Pequena Gramática do Português Brasileiro

Se, nas capas das gramáticas de Evanildo Bechara, observou-se que há uma afirmação da língua portuguesa (lusitana), em Castilho (2010) e Castilho e Elias (2012) depreende-se a afirmação do português brasileiro. A brasilidade é figurativizada na escolha das cores nacionais que compõem as capas, predominantemente o verde e o amarelo, com nuances de branco e azul, este último somente em Castilho (2010).

A oposição entre Português vs Brasileiro remete à discussão em torno do nosso idioma e organiza-se pelo jogo das cores e pela disposição do substantivo "Português" e do adjetivo "Brasileiro", colocados um abaixo do outro; a adjetivação, que acontece no plano de conteúdo, é reiterada no plano de expressão pelo uso do verde e do amarelo. Neste sentido, pode-se inferir que o português, ao qual os autores da obra se referem (não é o 
lusitano), é preenchido pela identidade nacional, seja na escolha do adjetivo, seja na escolha das cores. Ressalta-se, ainda, em toda a capa da gramática, matizada em verde e amarelo, o Brasil, o espaço nacional onde corre o rio gramatical (azul e branco), onde se empinam as pipas, atestando, como diria Ferrarezi Junior (2007), que o idioma adquire a nacionalidade do país em que é falado, não sendo mais o mesmo que lhe deu origem. ${ }^{7}$

Essa discussão expressa na oposição Português vs Brasileiro é, posteriormente, reafirmada pelo autor, na apresentação da obra:

Há mais de quinhentos anos a língua portuguesa foi trazida ao Brasil. Nos séculos XVI a XVIII foi rotulada como oportuguês no Brasil, pois era inteiramente lusitana, e não tinha superado as línguas indígenas. A partir do século XIX, a língua portuguesa tornou-se majoritária, começou a distanciar-se do português europeu, sendo então denominada português do Brasil. A partir dos anos 80 do século XX, suprime-se a preposição do, e começamos a falar em português brasileiro. Sinaliza-se com isso que novos distanciamentos tinham ocorrido, servindo a expressão para designar a identidade linguística dos brasileiros. (CASTILHO, 2010, p. 31 - grifos do autor).

Os barquinhos, navegando no rio gramatical, bem como as pipas em cores distintas (um/a verde e um/a amarelo/a), exprimem a diversidade dos usuários da língua presentes na nação; são distintos, assim como é o uso da língua, realizado por diferentes interlocutores, nas várias situações sociais, regiões geográficas.

Pode-se depreender, ainda, uma relação de dinamicidade vs não dinamicidade. O rio gramatical, construído a partir de linhas curvas, afirma a dinamicidade e nega a não dinamicidade (hegemonia da língua), reafirmada

\footnotetext{
7 “"...] o conceito de língua que adoto não privilegia a estrutura, mas o funcionamento representativo da língua inserida em uma cultura. Assim, a cada cultura em que um diferente sistema lingüístico se insere corresponderá uma nova língua. Desse ponto de vista, pode-se afirmar que no Brasil falamos o brasileiro [...] em Portugal se fala o Português [...] a língua tem seu funcionamento regido pelas peculiaridades daquela cultura" (FERRAREZI JUNIOR, 2007, p.17-18). É curioso ressaltar que o mesmo autor emprega essa concepção de nomenclatura da língua em uma gramática, intitulada Gramática do Brasileiro (FERAREZI JUNIOR; TELES, 2008).
} 
também pelo movimento "para cima" das pipas, denotando uma possível evolução.

A adjetivação do título "nova" remete à renovação/inovação da linguagem, das teorias que fundamentam a obra e a noção de ruptura com a gramática portuguesa, afirmando a identidade nacional.

Em Castilho e Elias (2012), nota-se no adjetivo "pequena" a proposta de uma gramática para ser levada à escola. Importante precisar que, a partir da publicação dos PCNs de língua portuguesa, o objeto de ensino da língua deixa de ser a gramática. Os autores, porém, asseveram, na apresentação, que a obra é articulada por três eixos: os Parâmetros Curriculares Nacionais; a incorporação das pesquisas desenvolvidas nos últimos trinta anos sobre o português brasileiro; e a convicção de que o ensino da língua portuguesa deve ser pautado na reflexão sobre a língua (CASTILHO; ELIAS, 2012, p. 13). Definem, portanto, que a gramática possui como fundamento uma teoria de língua e ensino pautados na língua como enunciação, processo, teorizada pela concepção de linguagem como interação.

A figura da pipa, no ar, recorda uma brincadeira de criança, feita a dois, de forma dialógica e interativa, e apresenta uma gramática que traz a possibilidade de estudar a língua nacional, brasileira, como algo prazeroso, diferente, é claro, de uma mera normatização. Em suma, "barco" e "pipa", enquanto construções artesanais de papel, apresentam características da individualidade, referente ao fazedor, e de coletividade, referente ao hábito de construir artefatos culturais. A relação de ambos com a gramática é perfeita, uma vez que ela, também, é uma espécie de produto (metalinguístico) cultural.

\section{Considerações Finais}

Cabe-nos ressaltar, na conclusão deste trabalho, que levantamos apenas algumas possibilidades de leitura das gramáticas que compuseram o corpus dessa pesquisa. Compreendemos, a partir da discussão aqui estabelecida, que a história das ideias linguísticas e a semiótica podem oferecer um aporte teórico para analisar o processo tecnológico de gramatização e possibilitar uma discussão profícua sobre os processos enunciativos que se instauram dentro do novo espaço geográfico de utilização do português, para perceber os deslizamentos e movimentos enunciativos que nos permitem olhar para os fatos da língua e avaliar as diferentes filiações teóricas e as consequências para a constituição da língua e da produção dos seus instrumentos de gramatização. 
Para um estudioso da língua e da linguagem, para um professor que trabalha com a formação, vale ressaltar que as ideias aqui apresentadas servem como aparato metodológico para uma análise crítica dos instrumentos de gramatização (gramáticas), nessa visão, instrumentos e objeto de estudo.

\section{Referências}

AUROUX, S. A revolução tecnológica da gramatização. Tradução de Eni Puccinelli Orlandi. Campinas: Edunicamp, 1992.

AUROUX, S. A hiperlíngua e a externalidade da referência. Tradução de Luiz Francisco Dias. In: ORLANDI, E. P. (Org.). Gestos de leitura: da história no discurso. Campinas: Edunicamp, 1994. p. 241-249.

AUROUX, S. A filosofia da linguagem. Tradução de José Horta Nunes. Campinas: Edunicamp, 1998.

BAKHTIN, M. Marxismo e filosofia da linguagem. Tradução de Michel Lahud e Yara Frateschi Vieira. São Paulo: Hucitec, 1995.

BAGNO, M. Português ou Brasileiro? Um convite à pesquisa. 4. ed. São Paulo: Parábola, 2004.

BARROS, D. L. P. de. Teoria do discurso: fundamentos semióticos. São Paulo: Humanitas, 2002.

BARROS, D. L. P. de. Teoria semiótica do texto. 4. ed. São Paulo: Ática, 2007.

BRASIL. Secretaria de Educação Fundamental. Parâmetros Curriculares Nacionais: língua portuguesa. Brasília, 1998.

CASTILHO, A. T. de. Variação dialetal e ensino institucionalizado da língua portuguesa. In: BAGNO, M. (Org.). Lingüistica da norma. São Paulo: Loyola, 2002.

DIAS, J. P. História das ideias linguísticas no Brasil: por uma reflexão sobre o movimento de edição do objeto histórico compêndio gramatical. In: SCHERER, A. E.; PETRI, V.; DIAS, C. (Orgs.). Tecnologias de linguagem e produção do conhecimento. Santa Maria: Editora do PPGLetras/UFSM, 2010. (Série HiperS@beres, v. II). 
FARINA, M.; PEREZ, C.; BASTOS, D. Psicodinâmica das cores em comunicação. 5. ed. São Paulo: Edgard Blücher, 2006.

FERRAREZI JUNIOR, C. Ensinar o brasileiro: respostas a 50 perguntas de professores de língua materna. São Paulo: Parábola, 2007.

FERRAREZI JUNIOR, C.; TELES, I. M. Gramática do Brasileiro. São Paulo: Globo, 2008.

FIORIN, J. L. Enunciação e Semiótica. Letras, Santa Maria, v. 33, p. 69-97, 2006.

FIORIN, J. L. Elementos de análise do discurso. 14. ed. São Paulo: Contexto, 2008.

GERALDI, J. W. (Org.). O texto na sala de aula. 3. ed. São Paulo: Ática, 2004.

GUIMARÃES, E. Sinopse dos estudos do português no Brasil: a gramatização brasileira. In: GUIMARÃES, E.; ORLANDI, E. P. (Orgs.). Lingua e cidadania: o português no Brasil. Campinas: Pontes, 1996. p. 127138.

MATTOS E SILVA, R. V. Dizem que vai mal o vernáculo no Brasil. In: MATTOS E SILVA, R. V. O Português são dois: novas fronteiras, velhos problemas. São Paulo: Parábola, 2004.

ORLANDI, E. P. (Org.). História das idéias lingüisticas: construção do saber metalingüístico e constituição da língua nacional. Campinas, SP: Pontes; Cáceres, MT: Unemat, 2001.

ORLANDI, E. P.; GUIMARÃES, E. Formação de um espaço de produção lingüística: a gramática no Brasil. In: ORLANDI, E. P. (Org.). História das idéias lingüisticas: construção do saber metalingüístico e constituição da língua nacional. Campinas, SP: Pontes; Cáceres, MT: Unemat, 2001, p. 21-38.

SAUSSURE, F. de. Curso de lingüistica geral. 4. ed. Tradução de Antônio Chelini et al. São Paulo: Cultrix, 1972.

TRAVAGLIA, L. C. Gramática e interação: uma proposta para o ensino de gramática nos $1^{\circ}$ e $2^{\circ}$ graus. 2. ed. São Paulo: Cortez, 1997. 


\section{Referências do corpus}

BECHARA, E. Moderna Gramática Portuguêsa. 8. ed. São Paulo:

Companhia Editora Nacional, 1963.

BECHARA, E. Moderna Gramática Portuguesa. 28. ed. São Paulo:

Companhia Editora Nacional, 1983.

BECHARA, E. Moderna Gramática Portuguesa. 37. ed. rev. Rio de Janeiro:

Nova Fronteira; Lucerna, 2009.

CASTILHO, A. T. de. Nova Gramática do Português Brasileiro. São Paulo:

Contexto, 2010.

CASTILHO, A. T. de.; ELIAS, V. M. Pequena Gramática do Português

Brasileiro. São Paulo: Contexto, 2012. 